\title{
SOME MOTIVATIONAL DETERMINANTS OF RACIAL DIFFERENCES IN INTELLECTUAL ACHIEVEMENT ${ }^{1}$
}

\author{
IRWIN KATZ \\ University of Micbigan, USA
}

\begin{abstract}
Motivations et différences raciales dans la réussite intellectuelle. - Dans les récentes années, un certain nombre de théories de la motivation ont été proposées, qui ne sont pas sans rapport avec le problème des différences raciales dans la réussite intellectuelle aux USA. Le modèle théorique du "désir de téussite" d'Atkinson suggère que pour des noirs qui se trouvent dans des situations scolaires à prédominance blanche, la valeur du succès est forte et faible l'espoir du succès, parce que les normes blanches de réussite sont plus élevées que celles des noirs. La distinction que fait Crandall entre l'origine interne et l'origine externe de la valeur et les normes de réussite, ainsi que les travaux de Crandall et al., sur le rôle de l'approbation de la mère dans l'émergence précoce des conduites de téussite, ont des implications pour l'étude des différences selon la classe sociale et la race dans le développement des motivations intellectuelles. La faible performance des élèves noirs paraît liée à l'inadéquation des renforcements à la maison et à l'école. La privation précoce d'approbation semble entrainer la formation de schèmes, se perpétuant d'eux-mêmes, de surdépendance à l'égard du milieu social en ce qui concerne les récompenses liées à la réussite et l'établissement des normes de réussite. Un autre chercheur, Rotter, a étudié les différences apparaissant entre les groupes et entre les individus, dans la tendance à percevoir les récompenses comme contrôlées de façon interne ou externe. Les noirs, enfants et adultes, ont un sens moindre du contrôle interne. Les conceptions précédemment évoquées peuvent être unifiées et utilisées pour rendre compte de façon substantielle des données dont on dispose sur la réussite des elèves noirs dans des écoles qui pratiquent la ségrégation ou l'intégration raciale.
\end{abstract}

It is of considerable scientific and practical significance that in all regions of the United States the scholastic performance of Negro youth is, on the average, inferior to that of whites. The achievement gap has always existed, yet psychologists and educators lack precise understanding of its causes. Until recently there was little research done on the problem, and most of it was narrowly concerned with the measurement of racial differences in IQ scores. There is now emerging a more promising trend toward studies of cognitive and motivational processes in the development of children from different socjal backgrounds. This paper will examine the academic achievement of Negro students from the standpoint of some general concepts of motivational processes underlying the development of intellectual achievement behavior.

1 The preparation of this paper was supported under research contract Nooo14-67-A-o18 I-0004 between the Office of Naval Research and the University of Michigan. 
The basic facts about the public education of Negro Americans were recently assessed by Coleman et al. (I 966) in a nationwide survey involving 645,000 pupils in over 4,000 elementary and high schools. This report describes conditions that have long been known to educators from informal observations. (a) On objective tests of scholastic achievement and ability, the average scores of Negroes at every grade level that was studied are about one standard deviation below white norms. This means that about $8 \mathrm{~s}$ per cent of the Negro school population test below white averages for their grade levels. The racial gap, when expressed in terms of Negro and white score distributions remains fairly constant in the North throughout the school years, while in the South it grows progressively larger from grade I to grade I 2. (b) In the North as well as the South most Negro students (about 66 per cent for the entire nation) attend public schools with predominantly nonwhite enrollments. (c) Throughout the country the quality of educational services, including school curriculums and facilities, and the verbal ability of teachers, that are available to minority group members are usually inferior to those enjoyed by whites in the same communities. These facts provide the background against which to examine motivational aspects of Negro performance in the classroom. A number of general concepts for analyzing achievement striving have been advanced during the last few years.

\section{THE ATKINSON MODEL OF ACHIEVEMENT MOTTVATION}

Atkinson (1964) has proposed a conceptual model of achievement motivation in which the strength of the impulse to strive for success on a given task is regarded as a joint function of the person's motive to achieve (measured as a personality characteristic), the subjective probability of success, and the incentive value of success. The notion of a motive to achieve, which grew out of McClelland's work on $n$ Achievement (McClelland et al., 1953), stresses a predisposition to experience gratification or its opposite in connection with self-evaluations of the quality of own performance. The incentive value of success is assumed by Atkinson to be equal to the apparent difficulty of the task, that is, to be an inverse function of the subjective probability of success. According to the model, on a task that has evaluative significance, e.g., a classroom test, motivation is maximal when the perceived probability of success is intermediate, i.e., is at the .50 level. One way in which the model has relevance for the study of minority group students is with respect to the effect of variations in the race of teachers and classmates on the expectancy of success, and the incentive value of success.

In a number of experiments the present author and associates found that Negro male college students tended to underperform on intellectual tasks when whites were present. These studies were reviewed in an article (Katz, 1964) which also speculated that for Negroes who find themselves in predominantly white academic achievement situations, the incentive value of success is high but the expectancy of success is low. This is because white standards of achievement are perceived as higher than own-race standards. By the same token, the perceived value of favorable evaluation by a white adult authority is high, but the expectancy of receiving it is low. Therefore, by experimentally controlling Negro subjects' expectancy of success on cognitive tasks it should be possible 
to produce the same, if not higher, levels of performance in white situations as in all-Negro situations.

Experiments have recently been carried out to test this line of reasoning. One study was done at a southern Negro college that has no admission criteria other than high school graduation. Most of the students had attended southern segregated public schools. Only a part of the experimental procedure and results need be described. Male freshmen were administered a digit-symbol task that was described as being part of a scholastic aptitude test. Their scores, they were told in advance, would be evaluated by comparison with the norms of certain other colleges, which they knew to have predominantly white student bodies. By means of false feedback about their scores on a previous practice trial of the same test, one third of the men were led to believe they had little chance of equalling the norm for their age group, one third were informed they had about an even chance, and one third were told they had a very good chance. Then half of the men in each probability-of-success condition were tested by a white person, and half were tested by a Negro person. The results showed that in the low and intermediate probability conditions, performance on the digit-symbol task was better with a Negro tester, but when the stated probability of achieving the white norm was high the performance gap between the two tester groups closed. Another finding of interest was that, in accordance with Atkinson's theory, highest performance with both Negro and white testers occurred in the intermediate probability condition.

Another experiment, very similar to the previous one, except that the task consisted of a series of simple arithmetic problems, was replicated on male undergraduates at two southern Negro colleges. One college has relatively high standards of admission which exclude the lower so percent of the state's Negro high school graduates, while the other college admits all high school graduates, regardless of their academic standing. At both colleges, most students had attended southern segregated public schools. In Table $\mathbf{I}$ the results are presented.

TABLE 1

EFFECT OF RACE OF TESTER AND PROBABILITY OF SUCCESS ON ARITHMETIC GAIN SCORES (POST-PRE) OF MALE STUDENTS AT TWO SOUTHERN NEGRO COLLEGES *

\begin{tabular}{|c|c|c|c|}
\hline & \multicolumn{3}{|c|}{ Probability of Success } \\
\hline & Low & Medium & High \\
\hline \multicolumn{4}{|l|}{ College A (Selective) } \\
\hline White Tester.... & 1.4 & 1.7 & 2.4 \\
\hline Negro Tester $\ldots \ldots \ldots \ldots \ldots \ldots$ & .8 & I.I & 1.3 \\
\hline \multicolumn{4}{|l|}{ College B (Nonselective) : } \\
\hline White Tester ............. & .4 & $\cdot 3$ & 1.9 \\
\hline Negro Tester..$\ldots \ldots \ldots \ldots \ldots$ & 2.I & 2.5 & 1.9 \\
\hline
\end{tabular}

* Significant main effects : College A, Race of Tester, $p<.05$; College B, Race of Tester, $p<.005$. Significant interaction : College B, Race $\times$ Probability of Success, $p=.05$.

It can be seen that at the nonselective college the effect of varying the race of tester was essentially the same as in the previous study, which used a different 
task. When the probability of success was low or intermediate, higher scores were obtained by the Negro tester groups, but in the high probability condition there was no tester difference. Turning now to the data from the selective college, scores were higher when the tester was white, regardless of the probability of success. At neither college was there a significant tendency for scores to peak in the intermediate probability condition. Summarizing, it appears that Negro students who had been average achievers in high school (the nonselective college sample) were discouraged at the prospect of being evaluated by a white person, except when they were made to believe that their chances of success were very good. But Negro students with a history of high academic achievement (the selective college sample) seemed to be stimulated by the challenge of white evaluation, regardless of the objective probability of success.

As yet, no studies of the type just described have been done on minority group students below the college level. It would be worthwhile to investigate in actual classtoom settings the dynamics of expectancy of success and incentive value of success as they are related to the race of the teacher and the race of the minority pupil's classmates. Indirect evidence from the Coleman survey tends to support this writer's assumptions that in predominantly white situations, the value of achievement is relatively high for the typical Negro student, while the expectancy of achievement tends to be low. The survey found that in predominantly white, as compared with segregated Negro, schools in the North, the Negro pupils have a stronger sense of opportunity for meaningful achievement, but less confidence in their own ability.

\section{INTERNAL VERSUS EXTERNAL SOURCES OF EVALUATION AND REWARD}

Crandall ( 1960 ) has focused on the development of achieving behavior in young children. Unlike Atkinson, who is primarily concerned with that component of the incentive value of success that arises internally, from the feeling of pride of accomplishment, Crandall attaches major importance to an external source of incentive value, the approval of significant other persons. Corresponding to internal and external sources of incentive value, in Crandall's formulation, are two types of achievement standard. Children and adults who are primarily motivated in achievement areas by the desire for approval, characteristically look to others to define the competence of their performance. Hence their standards mirror or reflect the standards or reactions of other persons and are designated reflective acbievement standards. On the other hand, persons who are internally motivated to achieve are apt to evaluate their own efforts almost exclusively on the basis of their own subjective achievement standards, tending to ignore the standards of others. Such individuals are said by Crandall to hold autonomous achievementi standards.

While Crandall does not elaborate this point, it is useful to think of the development of achieving behavior as a two-stage process. During the first stage, which begins as early as the second year of life in the white middle class home, the child's efforts to acquire language and solve problems are reinforced by strong expressions of approval from parents or parent surrogates. If the approval is given frequently yet selectively in response to reasonable efforts 
at mastery in a variety of verbal and cognitive areas, the child will eventually develop strong habits of striving for proficiency. To be maintained, these habits must continue to be reinforced in a consistent manner. The second stage of development is reached when parents' standards and values of achievement are internalized by the child. The process may be described as one in which the child's own implicit verbal responses acquire through repeated association with the overt responses of the parents, the same power to guide and reinforce the child's own achievement behaviors. That such verbal mediation processes occur in young children has been experimentally demonstrated by Russian psychologists in a series of ingenious conditioning experiments (reported by Razran, 1959). In all likelihood, internalization does not take place until strong, externally reinforced, achieving habits have developed. But there may be a considerable amount of overlap of the two stages, so that older children, and even adults may be impelled to achieve both by the desire for favorable self-evaluation, and the desire for the approval of others, the relative strength of each motive varying among individuals and also, perhaps, depending upon the type of achievement situation. Thus boys who are high achievers in high school have been found in a number of studies to be high on internal drive ( $n$ Achievement) and also docile, conforming and anxious (reviewed by Crandall, $19^{6}{ }_{3}$ ).

Unfortunately the evidence bearing on the role of social reinforcement in the early acquisition of achievement behaviors is both sparse and contradictory (reviewed by Crandall, 1963). The inconsistency in results is probably due to the research methods employed, most of the findings being based upon interviews, often retrospective, with parents and children, rather than direct observation of parent-child interaction. Even interviews with mothers of young children would not necessarily provide the relevant information about child behaviormaternal reinforcement contingencies, since the mother may not be fully aware of the extent to which her own responses and those of the child have mutually "shaped" one another. The few studies that have employed direct observation of parent-child interaction generally show a relationship between maternal approval and children's achievement striving. Crandall et al. (1960) observed the behavior of white middle class mothers and their preschool children in the home. Mothers who usually rewarded approval-seeking and achievement efforts had children who displayed more achieving behavior both in the home and in a nursery school free-play situation where the mother was not present. Other types of maternal behavior, such as reactions to children's help-seeking and emotional support-seeking, were not predictive of children's performance. Rosen and D'Andrade (I959) took achievement tasks into the homes of boys who had very high or very low $n$ Achievement scores, as measured projectively. Mothers of boys with strong $n$ Achievement were more inclined to give approval when performance was good and to criticize incompetent efforts. Although these mothers, according to the investigators, were more likely to give their sons more option as to exactly what to do, they gave less option about doing something and doing it well.

One may reasonably expect to find class and race differences in the extent to which parents reinforce language and problem solving behavior. In low income homes, where families tend to be large, and mothers often work during the day, each child generally gets less individual attention from adults than do children 
in middle class households. Also, because of their own educational deficiencies it is often difficult for lower class parents to know how to encourage intellectual behavior in their children, or even how to recognize it when it occurs. The study of class and race differences in maternal behavior by means of direct observation has hardly been attempted as yet, except by Hess and associates at the University of Chicago. In a pioneering study (Hess et al., 1966) they gave cognitive tasks to Negro mother-child pairs of different class backgrounds. Lower class mothers gave their children less praise for problem-solving attempts, and were less able to evaluate the quality of the child's responses.

The present assumption is that lower class children, and this would include most Negro children, because they have received less parental approval for early intellectual efforts, remain more dependent than middle class children on social reinforcement when performing academic tasks. Middle class children, who are likely to receive consistent social reinforcement of cognitive behavior in the home, have begun to internalize approval for success and standards of success by the time they enter elementary school. Children who have not been rewarded for intellectual efforts should tend to avoid intellectual achievement situations when they can, and to seek out more promising situations. But when constrained from avoiding intellectual activity, as in the classroom, they should display a high need for approval, and performance standards that are highly reflective of the immediate social environment. Crandall and others (1965 a) found that northern Negro elementary school pupils scored higher than white pupils on a test of the need for approval, patterned on the Crowne-Marlow Social Desirability Scale. Moreover, high scorers were likely to be shy, withdrawn, inhibited, and lacking in self-confidence. There is also some evidence from other studies, for example, one by Rosen (1959) that lower class Negro boys are very low on $n$ Achievement, which is here conceived as the capacity for self-praise and autonomous standard setting. Mingione (1965) found lower class Negro children to be lower on $n$ Achievement than white children of low socio-economic status.

The empirical evidence dealing with race and class differences in children's responses to social reinforcement is meager and inconsistent. Zigler and Kanzer (1962) did an experiment in which two types of verbal reinforcers, those emphasizing praise and those emphasizing correctness, were dispensed to white sevenyear-old boys working at a simple game-like task. Words connoting praise ("good" and "fine") were more effective reinforcers for lower class children than words connoting correctness ("right" and "correct"). The reverse was true for middle class children. However, a similar study by Rosenhan and Greenwald $(1965)$ did not bear out the findings. Neither class nor race differences were observed in the relative effect of praise and correctness feedback on children's performance of a simple conditioning task. More recently, Rosenhan (i966) obtained results which seem to contradict both of the earlier experiments. White and Negro lower class boys, as compared with white middle class boys, showed greater facilitation when told "right" for correct responses, and greater decrements when told "wrong" for incorrect responses on a simple probability learning task. Perhaps the inconclusiveness of the social reinforcement experiments can be attributed to a failure to control and manipulate certain critical variables, and to use appropriate tasks. None of the studies used verbal-symbolic 
tasks of the sort that reveal race and class differences in academic achievement, and none varied either the child's need for approval or the class-ethnic characteristics of the experimenter. The adult experimenter who dispensed rewards was always recognizably white middle class. It is entirely possible that the visible social status of an adult authority strongly infuences the socially disadvantaged child's interpretation of the adult's behavior.

Relating to this point is evidence that Negro and lower class children perceive their teachers as rejectant, and that the perceptions are to some extent veridical. Davidson and Lang ( 1960 ) found that, regardless of pupils' achievement level in school, those from blue-collar homes attributed to their teachers less favorable feelings toward them than did children from more advantaged homes. In another study, Negro students in northern integrated high schools described their white teachers as disinterested and insincere (Gottlieb, I964). White middle class teachers, it has been reported, do in fact tend to underestimate the ability of minority children, misinterpret their goals, and express a preference for teaching white pupils (Gottlieb, $196_{3}$; Haryou, 1964).

In a recent unpublished experiment the present writer and associates undertook to assess the extent to which the verbal learning of minority group children from blue-collar homes is influenced by praise or blame from a Negro or white adult in interaction with their need for approval. Northern urban Negro boys of elementary school age were individually administered a list of paired associates for Io trials. Subjects were assured at the outset that their performance would not affect their school grades. Half of the boys were tested by a Negro and half were tested by a white person. Also, half or them received periodic approval from the experimenter ("I'm pleased with the way you're doing", etc.) and half received periodic disapproval ("I'm disappointed in the way you're doing," etc.). Finally the sample was dichotomized into high and low on need for approval, measured before the learning task was introduced by means of a modified version of the Crowne-Marlow scale. Each boy's learning score was expressed as an average deviation (positive or negative) from the median learning scores of the total sample on three blocks of trials.

There were two main effects : More learning occurred with Negro testers than white testers, and more learning occurred when the tester gave approval than when he gave disapproval. But of greatest interest was an interaction of all three variables, the nature of which is revealed in Table 2. In order to account for the results, two types of assumptions will be made: (a) that the scale used to measure the need for approval actually tapped the subject's generalized predisposition to seek approval and avoid disapproval; and (b) that the Negro tester was perceived as predisposed to like the child and to react objectively to his performance, while the white tester was seen as inclined to dislike the child and to withhold genuine approval. The results shown in Table 2 can now be interpreted in the following manner: When the Negro tester was approving, all boys, regardless of need level, were adequately motivated for the task. When the Negro tester was disapproving, high-need boys were somewhat disheartened, but continued to seek approval. Their learning was somewhat poorer than in the Negro tester-approval condition, but not significantly so. Low-need boys, on the other hand, tended to lose interest in the task, since it was defined at the outset as having no academic significance. When the tester 
was white and gave approval, high need boys did not work quite as hard as boys who received approval from the Negro tester (difference non-significant). Though the white person's approval was seen as less genuine, their high need generated a moderate impulse to work, perhaps, in part, to avoid disapproval. Low-need boys were relatively unmotivated by whire approval. When the white tester was disapproving, high-need children experjenced debilitating anxiety, because the disapproval was taken as an overt expression of dislike; it was as though they could not hope to elicit a favorable response through greater expenditure of effort. The boys were virtually unable to learn at all. When low-need subjects were disapproved of by the white adult their performance did not deteriorate further. The slight nonsignificant improvement in scores over the white tester-approval condition is inexplicable except as a sampling error.

TABLE 2

CELL MEANS FOR INTERACTION EFFECT OF NEED FOR APPROVAL, RACE OF TESTER, AND TESTER RESPONSE ON LEARNING SCORES (EXPRESSED AS DEVIATIONS FROM MEAN OF TOTAL SAMPLE) OF NEGRO BOYS*

\begin{tabular}{l|c|c|c|c}
\hline \hline & \multicolumn{2}{|c|}{ Negro Tester } & \multicolumn{2}{c}{ White Tester } \\
\cline { 2 - 4 } & Approval & Disapproval & Approval & Disapproval \\
\hline High Need ........ & $2.4 \mathrm{I}$ & $\mathrm{I.42}$ & $\mathrm{I.24}$ & -3.80 \\
Low Need ........ & $2.5 \mathrm{I}$ & $-\mathrm{I} .33$ & $-\mathrm{I} .82$ & -.79 \\
\hline
\end{tabular}

* All differences between cell means of 2.04 and greater are significant at the .o5 level of probability by the Duncan Test.

The experiment shows that in order to understand the effects of positive and negative social reinforcement on Negro children it is necessary to take into account the need state of the individual child and the racial identity of the adult dispenser of reinforcement. Why the race of the tester influenced the verbal learning of northern urban Negro boys is not immediately apparent. While the assumption that the subjects felt less rapport with white experimenters is a reasonable one, there is no direct evidence to support it. Indeed, even if the assumption is valid, it is entirely possible that a relatively brief experience of friendly interaction with the adult would have changed the Negro child's responses in the learning situation. Therefore, the results may have implications not for biracial teacherpupil pairs per se, but only for situations in which the Negro child perceives the white person as hostile, unfriendly, or disinterested.

Summarizing, it has been suggested as being of some significance that lower class Negro children tend to be externally oriented in situations that demand performance. That it, they are likely to be highly dependent on the immediate environment for the setting of standards and dispensing of rewards. Some of the implications for educational practices are immediately apparent. First, teacher attitudes toward Negro children will be highly important for their classroom behavior. It has already been noted that attitudes of white teachers toward Negro pupils may generally be less than optimal. The evidence on this point is very 
sparse. Even the Coleman survey (Coleman et al, 1966) did not adequately assess teacher attitudes toward minority group pupils. Second, Negro students should be highly sensitive to the educational quality of both teacher and classmates, so that variations in these qualities should produce larger differences in the academic achievement of Negroes than of whites.

The Coleman report has data bearing upon the last point. It was found that the achievement of both Negro and white pupils, when their family background characteristics were partialled out, was more closely related to the educational proficiency of their classmates than to all objective school characteristics together (i.e., curriculum, expenditure per pupil, physical facilities, size of class, etc.), and to all reacher characteristics together. In the upper grades the apparent influence of the quality of the student body on individual achievement was two to three times greater for Negro pupils than for white pupils. The Coleman data represent correlations between variables, and causality must be inferred with utmost caution. Yet it seems a reasonable conclusion that a major part of the effect of the student body on individual achievement can be attributed to the high standards of performance set in the classroom. Teacher characteristics were almost as closely related to the Negro pupil's test scores as were student body characteristics. Teacher quality was much more important for Negro pupils than for white pupils. Beyond grade I Negroes were several times more sensitive to teacher variables than were whites. The most important characteristics of teachers were educational background and verbal ability.

Given the relatively high proficiency of white students and their teachers it is not surprising that as the proportion of white in a school increased, Negro achievement rose. The apparent impact of desegregation can be illustrated by comparing percentile scores on reading comprehension for northern Negro high school students who never had a white classmate with scores of northern Negroes with similar family backgrounds who attended integrated schools from the early grades. When figures from Table 3.3 .2 of the Coleman report are consolidated, it is revealed that Negro ninth graders with the longest experience of integrated schooling had an average score of 48.2. This is about five points below the white norm for the same region, but less than two points below the national norm of 50 . In contrast, ninth-grade minority group children who never had white classmates averaged 43.8. Thus it seems has desegregation reduced the racial achievement gap by almost half. The Coleman report also gives scores of twelfth graders, which were excluded from the present comparisons because the high rate of Negro dropouts makes them unrepresentative. Actually, the picture would not have been changed materially by their inclusion. When the influence of the student body's educational background and aspirations is controlled, the relationship between racial composition of schools and Negro test scores is sharply reduced. Thus the apparent beneficial effect of having a high proportion of white classmates comes not from racial composition per se, but from the high educational quality that is, on the average, found among white students.

Desegregation also appeared to have the effect of increasing the variability of Negro test scores. The differences in variance were small but consistent, and accord with notions advanced earlier in this paper regarding the complex determination of Negro motivation in predominantly white settings : because of the 
high prestige of white teachers and age peers, rejection by them is more disturbing to the Negro pupil, and their acceptance more facilitative, than similar responses from Negro teachers and peers. In addition, expectancy of success and value of success should tend to be affected in opposite ways by an increase in the proportion of white classmates, because of the elevation of achievement standards. Further unpublished analyses of the Coleman data by James McPartland (personal communication) reveal the expected difference between truly integrated and merely desegregated schools. Those schools with more than half white student bodies whose Negroes score well, when compared with similar schools whose Negroes score poorly, are characterized by greater cross-racial acceptance as predicted. Their students were much more likely to report close friends among members of the other race than students in the merely desegregated schools.

\section{SENSE OF CONTROL OF REWARDS}

Another valuable concept for understanding the educational achievement of children from different social backgrounds is Rotter's (Rotter et al., I962) sense of personal control of the environment. Individuals differ in the extent to which they feel they can extract material and social benefits from the environment through their own efforts. In its broadest meaning, this construct refers to the degree to which people accept personal responsibility for what happens to them. It has been applied more specifically to children in intellectual achievement situations by means of a questionnaire which assesses the extent to which favorable reactions from parents, teachers and peers are believed by the child to depend either upon the quality of his own efforts or upon extraneous factors (such as luck, or the personal bias or whim of the evaluator) (Crandall et al., I965b). A child's feelings about whether his own efforts determine his external rewards clearly will affect his perception of the attractivemess, or value of a given achievement goal, and his expectancy of success. The greater his need for approval in achievement situations, and the more his standards tend to be reflective, the closer will be these relationships. Crandall and others ( $1965 b$ ) found a tendency for sense for control and need for approval to be inversely related in white children. A reciprocal causal relationship should exist between beliefs about locus of control and achievement, since the beliefs will affect task motivation, and the level of performance will in turn affect the rate at which the environment dispenses rewards. Thus Crandall and others (1962) found that grade school boys who felt they controlled their reinforcements got high scores on intellectual tests and engaged in much intellectual free-play behavior. Similar results were obtained by Coleman and his coworkers. In this connection it is interesting to note that perception of internal control appears to be related to both white and middle class status (Battle and Rotter, ${ }_{963}$; Crandall et al., I965b; Coleman et al, I966).

In the Coleman survey, three expressions of student attitude were measured : interest in school work, self concept as regards ability, and sense of control of own fate. Of all the variables that were evaluated, including eight features of family background taken together, and a much greater number of objective school characteristics taken together, these attitudes showed the strongest relation to performance at all grade levels studied. For Negroes, perception of fate 
control was clearly the most important of the three attitudes. (To assess it, students were asked to respond to three statements - that "good luck is more important than hard work for success", that " every time I try to get ahead something or somebody stops me", and that "people like me don't have much of a chance to be successful in life ".) With or without family background characteristics partialled out, sense of fate control accounted for about three times as much variance in the test scores of Negroes as of whites at the higher grade levels, both in the North and South. White proficiency was more closely related to self concept than to control of environment. In the words of the Coleman report, " it appears that children from advantaged groups assume that the environment will respond if they are able to affect it; children from disadvantaged groups do not make this assumption, but in many cases assume that nothing they will do can affect the environment - it will give benefits or withhold them but not as a consequence of their own action." (p. 321). The crucial role of this factor in determining level of performance is suggested by the finding that Negro pupils who answered " hard work" scored higher on a test of verbal ability than did white pupils who chose the "good luck" response. Only a small fraction of the variance in fate control was accounted for by family background factors, and almost none of it by objective school characteristics. However, one variable is consistently related both to this attitude and to self concept. As the proportion white in the school increased, the Negro child's sense of internal control increased, but his self concept declined. It would appear that in integrated classrooms minority group children were less confident of their ability to compete, but were more aware of opportunity.

\section{SUMMARY}

Several motivational concepts have relevance to the problem of racjal differences in intellectual achievement in the United States. Among these are Atkinson's model of achievement motivation, Crandall's distinctions between external and internal sources of achievement standards and achievement value, and Rotter's notion of the locus of control. The purpose of this paper has been to suggest how these formulations can be integrated to account for many of the known facts about the performance of minority group students, and to suggest fruitful directions for future research. Among the broad research topics mentioned were race and class differences in the process whereby early social reinforcement of verbal-symbolic behaviors becomes internalized, race and class differences in external and internal dependency as related to academic motivation, and the role of expectancy of success and value of success on academic motivation. All of these factors need to be considered in the context of uniracial and biracial performance situations, with particular attention being given to the distinction between the racially integ rated classroom, in which the minority child experiences genuine acceptance, and the merely desegrated classroom, where the minority child feels unwelcome. 


\section{REFERENCES}

Atkinson, J.W. An introduction to motivation. New York : Van Nostrand, I964.

BAtrle, E. \& Rotter, J. Children's feelings of personal control as related to social class and ethnic group. Journal of Personality, 1963, 31, 482-490.

Coleman, J.S. et al. Equality of educational opportunity. U.S. Dept. Health, Educ. \& Welfare, Wash. : U.S. Govt. Printing Office, 1966.

Crandali, V.C., Crandale, V.J., \& Katkovsky, W. A children's social desirability questionnaire. Journal of Consulting Psycbology, 1965 a, 29, 27-36.

Crandall, V.C., Katkovsky, W., \& Crandall, V.J. Children's beliefs in their own control of reinforcements in intellectual-academic achievement situations. Child Development, 1965 b, 36, 92-109.

Crandali, V.J. Achievement. In Yearbook of the national society for the study of education. Chicago : The National Society for Study Education, 1963.

Crandali, V.J., Katkovsky, W., \& Preston, A. Conceptual formulation for some research on children's achievement development. Child Development, I960, 3I, 787,797.

Crandali, V.J., Katkovsky, W., \& Preston, A. Motivational and ability determinants of young children's intellectual achievement behaviors. Child Development, I962, 33, 643-661.

Crandall, V.J., Preston, A., \& Rabson, A. Maternal reactions and the development of independence and achievement behavior in young children. Child Development, I 960, 3I, 243-25 I.

Davidson, H.H., \& LANG, G. Children's perceptions of their teachers' feelings toward them related to self-perception, school achievement and behavior. Journal of Experimental Education, I960, 29, 107-II 8 .

GotTLIEB, D. Goal aspirations and goal fulfillments : Differences between deprived and affluent American adolescents. Unpublished paper, 1964 .

Gotrlieb, D. Teaching and students : The views of Negro and white teachers. Unpublished paper, 1963.

Harlem Youth Opportunities Unlimited, Inc. Youtb in the gbetto, New York, 1964.

Hess, R.D., Shipman, V. ,\& Jackson, D. Early experience and the socialization of cognitive modes in children. Child Development, I 965, 36, 869-886.

KATz, I. Review of evidence relating to effects of desegregation on the intellectual performance of Negroes. American Psychologist, 1964, 19, 381-399.

McClelland, D.C., Atkinson, J.W., Ciark, R.W., \& Loweli, E.L. The achievement motive. New York : Appleton-Century, 1953.

Mingrone, A. Need for achievement in Negro and white children. Journal of Consulting Psychology, 1965, 29, 108-111.

RazRaN, G. Soviet psychology and psychophysiology. Bebavioral Science, 1959, 4, 35-48.

Rosen, B. Race, ethnicity and the achievement syndrome. American Sociological Review, 1959, 24, 4I 7-460.

Rosen, B., \& D'Andrade, R.C. The psychological origins of achievement motivation. Sociometry, 1959, 22, I85-2 I 8 .

Rosenhan, D., \& GReEnwald, J.A. The effects of age, sex, and socioeconomic class on responsiveness to two classes of verbal reinforcement. Journal of Personality, I965, 33, I08-I 21.

RosenHAN, D. Effects of social class and race on responsiveness to approval and disapproval. Journal of Personality and Social Psychology, 1966, 4, 253-259.

RotTer, J, SEEMAN, M, \& LrVERAN', S. Internal vs external control of reinforcement : A major variable in behavior theory. In N.F. Washburne (Ed.), Decisions, values and groups. Vol. 2. London : Pergamon Press, i962.

Zigler, E., \& KANZER, P. The effectiveness of two classes of verbal reinforcers on the performance of middle-class and lower-class children. Journal of Personality, 1962, 30, 157-163. 